\title{
Legal Standing of Victims in Criminal Proceedings: \\ Wickham v Magistrate, Stellenbosch 20171 BCLR 121 (CC)
}

\section{P.E.R}

Pioneer in peer-reviewed, open access online law publications

Authors

Lindelwa Mhlongo

Angelo Dube

Affiliation

University of South Africa

Email mhlonlb@unisa.ac.za dubeba@unisa.ac.za

Date Submission

7 February 2019

Date Revised

22 January 2020

Date Accepted

22 January 2020

Date published

5 May 2020

Editor Prof T Mmusinyane

How to cite this article

Mhlongo $L$ and Dube A "Legal Standing of Victims in Criminal Proceedings: Wickham $v$

Magistrate, Stellenbosch 20171 BCLR 121 (CC)" PER / PELJ 2020(23) - DOI

http://dx.doi.org/10.17159/17273781/2020/v23i0a6022

Copyright

http://dx.doi.org/10.17159/17273781/2020/v23i0a6022

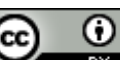

\section{DOI \\ Cc)}

\begin{abstract}
In late 2016, the Constitutional Court delivered judgment in a case, Wickham v Magistrate, Stellenbosch 20171 BCLR 121 (CC), involving Wayne Anthony Wickham (an aggrieved father and applicant in this case), who appealed against the decision of the Magistrate's Court in which he was denied the opportunity to hand up a victim impact statement. The thrust of his application was that his rights, as a victim of the crime in which his son was negligently killed by the fourth respondent, had been violated, and that this raised an arguable point of law of general public importance. The respondents, however, argued that the applicant lacked standing as the dominus litis in culpable homicide cases is the public prosecutor, and not the relatives of the deceased, or the victim. The case turned on whether the exercise of discretion by the Magistrate in denying Wickham the right to be heard was performed correctly; and whether a nonparty to criminal proceedings could make an application for the review of the Magistrate's conduct. The article seeks to interrogate the rights of victims in criminal proceedings and aptly poses the following question: Do victims of crimes have a locus standi to be part of criminal proceedings?
\end{abstract}

\section{Keywords}

Victims of crime; victim impact statements; criminal proceedings; court's discretion; legal standing; judicial review; Victims Charter. 


\section{Introduction}

In October 2016 the Constitutional Court delivered a very brief, 12-page unanimous judgment in the matter of Wickham v Magistrate, Stellenbosch, ${ }^{1}$ which is a matter that started in the Magistrate's Court. The final determination of the matter followed a series of similar applications brought by Mr Wayne Anthony Wickham, whose son was killed in an auto accident by the negligent actions of Ms Annika Slabbert. Also cited as respondents in the case were the Magistrate (Stellenbosch), the Director of Public Prosecutions, Western Cape (DPP), the Minister of Justice and Constitutional Development, as well as the convict, Ms Slabbert. In the first instance, Mr Wickham had instituted an original application directly to the Constitutional Court for leave to appeal. ${ }^{2}$ In dismissing the matter, the Constitutional Court held that it was not in the interests of justice to hear the matter at that time because the Supreme Court of Appeal (SCA), which had jurisdiction, had not yet been approached.

Following Mr Wickham's unsuccessful Constitutional Court application, he approached the SCA for leave to appeal the Magistrate's decision. Simultaneously with this application, another application was initiated directly in the SCA. These two attempts were also unsuccessful. Having exhausted all available remedies, Mr Wickham decided to re-launch his application in the Constitutional Court, as an appeal against the High Court decision which dismissed his initial appeal against the conviction and sentence handed down by the Magistrate's Court.

\section{The litigation history of the current case}

The bone of contention was that the Magistrate had accepted a plea agreement between the DPP and Ms Slabbert "without offering Mr Wickham" a chance to table his victim impact statement. Mr Wickham claimed that he had been distressed and suffered anxiety as a result of the

Lindelwa Mhlongo. LLB LLM (UNISA). PhD candidate and lecturer, Department of Public, Constitutional and International Law, College of Law, University of South Africa. E-mail: mhlonlb@unisa.ac.za. ORCID ID https://orcid.org/0000-0002-60518480.

** Angelo Dube. BA LLB (Swaziland) LLM (UWC) MBL (UNISA) LLD (UWC). Professor at the Department of Public, Constitutional and International Law, College of Law, University of South Africa. E-mail: dubeba@unisa.ac.za. ORCID ID https://orcid.org/0000-0001-6959-2401.

1 Wickham v Magistrate, Stellenbosch 20171 SACR 209 (CC) (hereafter Wickham v Magistrate).

$2 \quad$ Wickham v Magistrate para 3. 
prosecution's and the court's failing to give adequate regard to his concerns as a "parental victim of the crime". ${ }^{3}$

Ms Slabbert had entered into a plea agreement in terms of section 105A of the Criminal Procedure Act 51 of 1977 (CPA). Section 105A(1)(a) of the CPA provides that:
A prosecutor authorised thereto in writing by the National Director of Public Prosecutions and an accused who is legally represented may, before the accused pleads to the charge brought against him or her, negotiate and enter into an agreement in respect of - (i) a plea of guilty by the accused to the offence charged or to an offence
of which he or she may be convicted on the charge.

The CPA further provides in paragraph (b) that the prosecutor may enter into an agreement as set out above:

\begin{abstract}
[a]fter affording the complainant ..., where it is reasonable to do so and taking into account the nature of and circumstances relating to the offence and the interests of the complainant, the opportunity to make representations to the prosecutor regarding-
\end{abstract}

(aa) the contents of the agreement.

Having accepted the plea agreement entered into in terms of the law above, the Magistrate's Court imposed a fine of R10 000 or 12 months' imprisonment which was conditionally suspended for three years. Ms Slabbert was also given an additional 18 months of correctional supervision. ${ }^{4}$

In his appeal to the High Court, Mr Wickham sought an order setting aside the conviction and sentence of Ms Slabbert. Further, that the High Court should order a remission of the matter to the Magistrate's Court at Stellenbosch for a fresh hearing presided over by a different officer. The High Court challenge was aimed at ensuring that Mr Wickham would get his opportunity to introduce evidence in aggravation of sentence, which would include a victim impact statement. He also sought to have the DPP compelled to place before the court evidence in aggravation, should the court convict Ms Slabbert in the new trial. ${ }^{5}$ Mr Wickham's application in the High Court was dismissed for two reasons, namely: he lacked standing to have the plea and sentence agreement set aside; and the Magistrate's failure to exercise his discretion in terms of section $105 \mathrm{~A}(7)(\mathrm{b})(\mathrm{i})(\mathrm{bb})$ of the

Wickham $v$ Magistrate para 1.

Wickham v Magistrate para 13.

Wickham v Magistrate para 14. 
CPA on whether to hear Mr Wickham's evidence or his victim impact statement could not be reviewed at his instance. ${ }^{6}$

In dealing with the first ground, being the lack of standing, the High Court was of the view that the obligation to afford complainants an opportunity to make representations falls squarely on the prosecutor. However, such an obligation exists only where it is reasonable to do so in the light of all the circumstances relating to the offence, as well as the interests of the complainants themselves. Failure to do this, where it would otherwise be reasonable to do so, is unlawful. ${ }^{7}$

The complainant's standing under these circumstances flows from the Promotion of Administrative Justice Act 3 of 2000. In the case at hand, however, the High Court found that Mr Wickham had been afforded a far more extensive opportunity than most victims. The DPP embarked on the plea agreement only after hearing Mr Wickham, and as such he lacked standing to set aside the plea and sentence agreement. ${ }^{8}$

On the second point regarding the reviewability of the exercise of discretion by the Magistrate, the High Court pointed out that victims are not party to criminal proceedings and as such they do not have an automatic right to present evidence. Mr Wickham's victim impact statement mostly discussed the merits of the case. What compounded his situation was that the facts he presented were inconsistent with the factual matrix agreed upon between the DPP and Ms Slabbert. In the light of the foregoing, the High Court concluded that the Magistrate had exercised his discretion fairly, and that there was no irregularity on his part. As such, his actions could not be subjected to review. ${ }^{9}$

It is worth noting that the High Court did take into consideration $\mathrm{Mr}$ Wickham's feelings as a victim of Ms Slabbert's negligent behaviour. ${ }^{10}$ It stated that "it would have been preferable ... for the Magistrate to have exercised some degree of judicial maturity, civility and empathy." This could have been done through allowing Mr Wickham some latitude to express his feelings at having lost his son. The court cautioned, however, that such indulgence could be granted only provided it did not lead to the infringement of the rights of Ms Slabbert. ${ }^{11}$ The Constitutional Court also endorsed the

Wickham v Magistrate para 15.

Wickham $v$ Magistrate para 16

Wickham $v$ Magistrate para 16.

Wickham v Magistrate para 18.

Wickham v Magistrate para 19.

Wickham v Magistrate para 19. 
High Court's view on the civility of the Magistrate, noting that "the loss of a child is a terrible and difficult one to bear" and as such even courts ought to show sympathy and respect. ${ }^{12}$

\subsection{Unsuccessful attempts to approach the Constitutional Court directly}

Mr Wickham's initial application to the Constitutional Court was dismissed. He had instituted a direct application for leave to appeal to the Constitutional Court, thereby bypassing the SCA, which ordinarily had jurisdiction. ${ }^{13}$ The Constitutional Court was of the view that doing so would not be in the interests of justice. The Constitutional Court has placed heavy emphasis on this principle over time. It has indicated that it does not want to be a court of first and last instance, and wants to benefit from having the issues that come before it being subjected to scrutiny by the subordinate courts first.

In AParty v Minister of Home Affairs; Moloko v Minister of Home Affairs ${ }^{14}$ the Constitutional Court stated that it needed very compelling reasons to depart from its ordinary procedure and to exercise its discretion to grant direct access. Amongst these considerations is the determination of the prospects of success of an application. The fact that the court is called upon to hear a case without the benefit of the views of other courts having constitutional jurisdiction is also taken into account by the court in deciding on an application for direct access. ${ }^{15}$

Following the unsuccessful application for direct access to the Constitutional Court, Mr Wickham instituted a two-pronged application; he simultaneously applied for leave to appeal to the SCA via the High Court, whilst at the same time instituting a direct application to the SCA. He was unsuccessful in both applications.

\subsubsection{The case before the Constitutional Court}

Not satisfied with the SCA ruling, Mr Wickham approached the Constitutional Court, where he sought to overturn the decision of the court a quo.

Wickham v Magistrate para 34

Wickham $v$ Magistrate para 3.

AParty v Minister of Home Affairs; Moloko v Minister of Home Affairs 20093 SA 649

(CC) para 30.

15

Bruce v Fleecytex Johannesburg CC 19982 SA 1143 (CC) para 7. 
He sought to prove that his application raised an arguable point of law of general public importance. His main argument was that the High Court's decision set a precedent which will undermine the rights of victims as set out in the Victims' Charter in future criminal proceedings. ${ }^{16}$

The Victims' Charter is a Charter of Rights adopted in terms of section 234 of the Constitution, which empowers Parliament to adopt Charters of Rights consistent with the Constitution. Section 234 provides that:

In order to deepen the culture of democracy established by the Constitution, Parliament may adopt Charters of Rights consistent with the provisions of the Constitution.

The Victims' Charter serves as a means of protecting and promoting the rights of victims in compliance with South Africa's obligations under various international and regional human rights instruments. These include the United Nations Declaration of Basic Principles of Justice for Victims of Crime and Abuse of Power, the United Nations Convention on the Elimination of All Forms of Discrimination against Women and the United Nations Convention on the Rights of the Child.

Mr Wickham argued before the Constitutional Court that the Magistrate's rulings, in regard to both the victim impact statement and his proposed oral evidence, were grossly irregular and constituted a denial of his rights as a victim to participate in the proceedings. ${ }^{17}$ The unanimous decision, however, placed emphasis on the fact that just like the rights in the Bill of Rights, those rights contained in section 2 of the Victims' Charter are not absolute.

\subsubsection{Locating the rights of victims}

Ordinarily, the rights in the Bill of Rights can be limited in two ways: by relying on section 36 of the Constitution, and by employing any internal limitation that may be contained in the specific provision under scrutiny.

The section 2 rights of victims can be traced back to sections 34 and 16 of the South African Constitution, which regulate access to courts. Section 34 stipulates that "Everyone has the right to have any dispute that can be resolved by the application of law decided in a fair public hearing before a court or, where appropriate, another independent and impartial tribunal or

\footnotetext{
$16 \quad$ Wickham $v$ Magistrate para 20.

17 Wickham $v$ Magistrate para 26.
} 
forum". Section 16 recognises the freedom of everyone to receive and impart information.

The Constitutional Court did not attempt to locate this right in the Bill of Rights. It simply focussed on section 2 of the Victim's Charter, and concluded that indeed Mr Wickham did have such a right, before proceeding to its limitation. Perhaps this can be attributed to the changes brought about by the Constitution's Seventeenth Amendment, which broadened the scope of the court from "constitutional matters" to include matters that raise an arguable point of law of general public importance. In other words, it is no longer necessary for a litigant to establish that his or her case raises a constitutional matter, so long as the other leg is established; that is that the matter raises an arguable point of law of general public importance that ought to be decided by the Constitutional Court. ${ }^{18}$ Perhaps that is the reason the court no longer strives to locate a right in the Bill of Rights as it did in constitutional or Bill of Rights litigation cases before. For instance in Nyathi $\checkmark$ MEC for Health, Gauteng, Madala $\mathrm{J}$ first delineated the constitutional issues before the court. He went on to enquire if the impugned legislation limited any rights in the Bill of Rights before determining whether that limitation was justifiable. ${ }^{19}$ All the foregoing notwithstanding, it is our view that section 2 of the Victim's Charter flows from sections 16 and 34 of the Constitution. This is further buttressed by the fact that that Victim's Charter itself is sanctioned by section 234 of the Constitution.

Indeed, this resonates with the Constitutional Court's view that $\mathrm{Mr}$ Wickham's rights as a victim are to be located in the Charter, which itself flows from the Constitution. Hence the court noted that the introductory sentence to the rights in the Charter states that "the following rights, as contained in the Constitution and relevant legislation, will be upheld during your interaction with the criminal justice system".

The limitation clause contained in section 36 provides that "The rights in the Bill of Rights may be limited only in terms of law of general application to the extent that the limitation is reasonable and justifiable in an open and democratic society based on human dignity, equality and freedom ...". The same provision enjoins the court to consider the following factors in determining whether a right has been lawfully limited or not: the nature of the right; the importance of the purpose of the limitation; the nature and

\footnotetext{
$18 \quad$ Booysen v Minister of Safety and Security 20186 SA 1 (CC) para 47.

$19 \quad$ Nyathi v MEC for Health, Gauteng 20085 SA 94 (CC) para 34.
} 
extent of the limitation; the relation between the limitation and its purpose; and less restrictive means to achieve the purpose.

Apart from section 36 , rights can also be subjected to internal limitations. This is the case where the provision itself contains clearly defined parameters within which the right in question is to be enjoyed.

It is clear from the above that the rights of victims can be limited, albeit through internal limitations contained within section 2 itself. The text of the Charter employs such terms as "where appropriate", and "if necessary and where possible". It also uses the discretionary word "may" in dealing with the right of the victim to make a statement to the court or give evidence during the sentencing proceedings to bring the impact of the crime to the court's attention. It is clear from the wording of the Charter that such rights are therefore not unqualified, as Mr Wickham implied.

Section 2 of the Victim's Charter also draws its strength from section $105 \mathrm{~A}(1)(\mathrm{b})(\mathrm{iii})$ of the Criminal Procedure Act, which provides that a prosecutor may enter into an agreement contemplated in section 105A(1)(a) after affording the complainant (or his representative) an opportunity to make representations to the prosecutor. This provision is subject to internal limitations too. It is thus qualified by the words "where it is reasonable to do so" and "taking into account the nature of and circumstances relating to the offence and the interests of the complainant".

\subsubsection{Standing in constitutional matters}

What can be gleaned from the judgment of the Constitutional Court is that the Victims' Charter does not confer standing. ${ }^{20}$ What this means is that applicants in the position of Mr Wickham should, over and above asserting their section 2 rights, also establish that the prerequisites of standing as laid out in section 38 of the Constitution are met. These include that the applicant is:

a) acting in his own interest;

b) acting on behalf of another person who cannot act in their own name;

c) acting as a member of a group or class of persons;

d) acting in the public interest; and

$20 \quad$ Wickham $v$ Magistrate para 27. 
e) an association acting in the interests of its members.

Mr Wickham failed to establish standing under any of the grounds listed in section 38. It is generally considered that own interest standing is regarded as weightier than that in the other categories. A person must show that a contested law or decision directly affects his or her interest or rights. ${ }^{21}$ In Ferreira $v$ Levin ${ }^{22}$ the court held that the interests or rights protected must be real and not hypothetical or academic. ${ }^{23}$ The court further held that a hypothetical interest is one that is expressly claimed but is neither real nor true. For this reason, a person may be denied standing even though the result could be that an unlawful decision stands.

The second and third categories of persons listed in section 38 with standing did not apply to Mr Wickham as he was acting on his behalf and he was also not a member of any group or class of persons.

The fourth category is that the person must act in the public interest. In order for a person to be afforded standing with regard to this category, it must be shown first that the person is acting in the public interest and secondly that the public has sufficient interest in the requested remedy or outcome. ${ }^{24}$ The public interest is generally on a basis wider than those in the class actions as provided for in section 38(c) of the Constitution. In the Ferreira case the court also dealt with factors which can assist in determining whether a person is acting in the public interest or not. In this regard, the court held:25

\begin{abstract}
Whether there is another reasonable and effective manner in which the challenge can be brought; the nature of the relief sought, and the extent to which it is of general and prospective application; and the range of persons or groups who may be directly or indirectly affected by any order made by the court and the opportunity that those persons or groups have had to present evidence and argument to the court.
\end{abstract}

Mr Wickham did not fall in this category as the remedy he sought was personal and did not cover any group of persons. Therefore, his argument that he was raising a "point of law of general public importance" could not stand. Mr Wickham did not fall under the last category because he was not an association.

\title{
3 Determining standing in criminal matters
}

\footnotetext{
$21 \quad$ Currie and De Waal Bill of Rights Handbook 80.

22 Ferreira $v$ Levin 19961 SA 984 (CC).

23 Ferreira $v$ Levin 19961 SA 984 (CC) paras 160, 164-165.

$24 \quad$ Currie and De Waal Bill of Rights Handbook 83.

25 Ferreira $v$ Levin 19961 SA 984 (CC) para 234.
} 
In Uffindell t/a Aloe Hunting Safaris v Government of Namibia, the court held that whether a litigant's interest in the subject matter of the litigation justifies the engagement of the court's judicial powers must be assessed with regard to the peculiar facts and circumstances of each case. The interest the litigant claims to have must not be abstract, academic, hypothetical or simply too remote. ${ }^{26}$ The opinion of the court in Minister of Police $v$ NP Sosibo supports the view that only the state, through the office of the DPP, has locus standi in criminal cases, and not the victim per se. ${ }^{27}$

The power to institute criminal proceedings as contemplated by section 179 of the Constitution vests in the National Prosecuting Authority, which is the only authority empowered to institute and conduct criminal proceedings on behalf of the state. In other words, the prosecutor is dominus litis. The DPP decides whether or not to prefer charges, the nature of the charges to prefer, what plea to accept and on what basis, what evidence to lead and what sentence to suggest to the court. ${ }^{28}$

The Constitutional Court noted that both the Magistrate and Ms Slabbert's attorney agreed that Mr Wickham lacked standing, and as such could not hand up a victim impact statement in court. ${ }^{29}$ This position was endorsed by the Constitutional Court as well.

\subsection{Obfuscating judicial reasoning on the issue of standing}

Standing in legal proceedings basically means that a litigant must have capacity to sue and also have a sufficient interest in the proceedings. ${ }^{30}$ The question is whether it is the same as dominus litis?

In criminal matters the designation of the prosecutor as dominus litis means that he is regarded as the person in control of the criminal proceedings. He determines not only whether adjudication takes place, but also the charges to be preferred. The only exception is in the case of a private prosecution, where the private prosecutor is dominus litis. ${ }^{31}$

Uffindell t/a Aloe Hunting Safaris v Government of Namibia 2009 NAHC 51 para 12.

Minister of Police v NP Sosibo 2010 ZAKZPHC 102 (14 December 2010) para 5. It was held in the appeal case in which the DPP had been cited as the fourth respondent that the right to prosecute vests in the DPP, and only the DPP had the necessary locus standi to have launched the application.

$28 \quad$ Wickham $v$ Magistrate 92 and 41.

29 Wickham $v$ Magistrate para 12.

30 Baxter Administrative Law 644

31 Kurland and Water 1959 Duke Law School Journal 493. 
Standing, on the other hand, is not necessarily synonymous with dominus litis. Whilst the party considered to be dominus litis must as a matter of fact also have standing in a particular matter, there is no requirement that all parties with standing be regarded as dominus litis. A good example is where a litigant acts as amicus curiae, who joins the proceedings on account of his or her interest in the matter, without necessarily seeking to become or actually becoming dominus litis. The party who initiated the litigation remains dominus litis, even after the amicus is allowed to join the proceedings.

Thus the courts' reference to the fact that the state and not the victim is dominus litis seems to have unfairly swayed the court towards the conclusion that Mr Wickham lacked standing, thereby conflating standing with dominus litis. ${ }^{32}$

The Constitutional Court made a very bold statement in relation to standing where it held that section 2 of the Victim's Charter neither confers standing nor an unqualified right to give evidence or to hand up papers to a victim of crime. ${ }^{33}$ This implied that the issue of standing still had to be resolved using the parameters contained in section 38 of the Constitution, which the Constitutional Court regrettably did not address.

\subsubsection{Who is a victim under the Charter?}

South African law does not define what or who a victim is. The National Policy Guidelines for Victim Empowerment, ${ }^{34}$ however, attempts to proffer an explanation as to who can be classified as a victim. A victim is any person who has suffered harm, including physical or mental injury; emotional suffering; economic loss or substantial impairment of his or her fundamental rights, through acts or omissions that are in violation of the criminal law. This explanation implies that there must be a direct connection between the victim and the crime committed. In other words, the effects of the crime must primarily have affected the victim. The Guidelines continue to stipulate that even when a crime indirectly effects a person, such a person will qualify as a victim. This includes indirect victims such as the immediate family or dependents or even neighbours or colleagues of a direct victim. The South African model of ensuring justice for victims seeks to promote victim 
empowerment. It is informed by the need for a victim-centred approach to criminal justice, as well as the aspirations of restorative justice. ${ }^{35}$

The Guidelines almost mirror the definition of a victim contained in the Australian Victim's Charter Act. The Australian Charter, in section 3, lists three categories of people who can claim to be victims. ${ }^{36}$ These are (a) a natural person who has suffered injury as a direct result of a criminal offence, whether or not that injury was reasonably foreseeable by the offender; or (b) if a person has died as a direct result of a criminal offence committed against that person, a family member of that person; or (c) if the person referred to in paragraph (a) is under 18 years of age or is incapable of managing his or her own affairs because of mental impairment, a family member of that person.

The Promotion of National Unity and Reconciliation Act 34 of 1995 contains a broad understanding of the term "victim". Victims include: persons who individually or collectively with one or more persons suffered harm as a result of a gross violation of human rights; or as a result of an act associated with a political objective for which amnesty has been granted. Persons who individually or collectively with one or more persons suffered harm as a result of their trying to intervene and assist persons listed in the first category. The last category relates to relatives and dependants of victims as may be prescribed.

The South African Law Commission defines a victim as a biological person who has suffered harm at the hands of another person in the course of a crime of violence.

The South African Victims Charter embraces the definition of a victim contained in the UN Declaration of Basic Principles of Justice for Victims of Crime and Abuse of Power, which is couched as follows: ${ }^{37}$

A person who has suffered harm, including physical or mental injury, emotional suffering, economic loss or substantial impairment of his or her fundamental rights through acts or omissions that are in violation of our criminal law. 'Victim' also includes, where appropriate, the immediate family or dependant of the direct victim. A person may be considered a victim regardless of whether the perpetrator is identified, apprehended, prosecuted or convicted and regardless of the familial relationship between the perpetrator and victim. 'Victim' is inclusive of all, without prejudice of any kind on the grounds of race, gender, sex, pregnancy, marital status, ethnic or social

35 UN ODCCP Handbook on Justice for Victims 3.

36 Victims' Charter Act 65 of 2006.

37 Article 1 of the United Nations Declaration of Basic Principles of Justice for Victims of Crime and Abuse of Power (1985). 
origin, colour, sexual orientation, age, disability, religion, conscience, belief, culture, language and birth.

The Draft United Nations Convention on Justice and Support for Victims of Crime and Abuse of Power (2006) defines victims as natural persons who, individually or collectively, have suffered harm, including physical or mental injury, emotional suffering or economic loss or violations of fundamental rights in relation to victimisations identified under "scope". The scope that the UN Convention envisages includes violations of criminal laws; abuses of power; acts of terrorism; and acts of human trafficking. ${ }^{38}$

The African Union Principles and Guidelines on the Right to Fair and Legal Assistance in Africa also mirrors the definition in the Draft UN Convention and provides that: 39

\footnotetext{
Victim means a person or persons who individually or collectively have suffered harm, including physical or mental injury, emotional suffering, economic loss or substantial impairment of their fundamental rights, through acts or omissions that are in violation of criminal laws or that do not yet constitute violations of national criminal laws but of internationally recognised norms relating to human rights.
}

Mr Wickham qualified as a victim since he had a paternal relationship with his late son. He could thus be referred to as a relative or a family member of the deceased, and hence he had an interest in the outcome of the matter.

\subsection{What is a victim impact statement and what purpose does it serve?}

Section 2 of the South African Victims' Charter provides that the victim has a right to offer information during the criminal investigation and trial. It further requires the prosecutor to take measures to ensure that any contribution that the victim wishes to make is considered when deciding to prosecute. Further, the victim can if necessary and where applicable attend the bail hearing, the trial, the sentencing and the parole board hearing. Lastly, the victim has the opportunity to make a further statement to the police if he/she realises that the first statement is incomplete.

A victim impact statement, in part, serves to empower the victim, as a part of the restorative justice process. The South African Law Commission views restorative justice as a process that seeks to redefine crime, interpreting it

$38 \quad$ Articles 1 and 2 of the Draft United Nations Convention on Justice and Support for Victims of Crime and Abuse of Power (2006).

39 African Union Principles and Guidelines on the Right to Fair and Legal Assistance in Africa (2003). 
not so much as breaking the law or offending against the State but as an injury or wrong done to another person. Erez ${ }^{40}$ defines a victim impact statement as a statement which would "address the effects of the crime on the victim, in terms of the victim's perceptions and expressions of the emotional, physical or economic harm he or she sustained as a result of the crime". Apart from being therapeutic, victim impact statements also serve to improve sentencing outcomes and enhance the criminal justice system as a whole. It should be noted, however, that a victim impact statement does not confer judicial powers or prosecutorial powers on the victim. As such, the statement must refrain from dealing with the merits of the case. Thus, a victim impact statement should preferably not include a reference to a recommended sentence. The danger of doing this is that it may tend to tarnish or neutralise the value of the victim impact statement, should the recommendation be overly emotional. ${ }^{41}$

Erez and Rogers define a victim impact statement as a written or oral statement made by the victim in which the victim expresses the (financial, social, psychological and physical) harm s/he has experienced as a part of the court proceedings. The growing utilisation of victim impact statements has caused a shift from the individualisation of the offender to the individualisation of the victim. This development introduced a shift from the conceptualisation of crime as a violation against the state and not individual victims. Kelly argued that this shift would remind judges, juries and prosecutors that behind the state is a real person with an interest in how the case is resolved. ${ }^{42}$ Chalmers argues that these interventions have therapeutic value on victims. ${ }^{43}$ Lens et al, however, while echoing the definition by Erez and Rogers, ${ }^{44}$ proceed to state that there is no empirical evidence that delivering victim impact statements gives rise to direct "therapeutic" effects. However, their study did reveal that feelings of anxiety decreased for victims who experienced higher feelings of procedural justice. ${ }^{45}$ They further discovered that increasing feelings of control over the recovery process could lead to a decrease in feelings of anger and anxiety amongst victims.

In the current case, the prosecutor gave Mr Wickham the opportunity to be heard by requesting a victim impact statement, which he undertook to attach

Erez 1995 Crim LR 545.

Muller and Van der Merwe 2006 SAJHR 658.

Kelly 1987 Wayne L Rev 69-86.

Chalmers, Duff and Leverick 2007 Crim LR 360-379.

Lens et al 2015 Eur J Criminol 19.

Lens et al 2015 Eur J Criminol 31. 
to the plea and sentencing agreement. Mr Wickham, however, prepared a victim statement which dealt with the merits of the case based on facts that were inconsistent with the factual matrix agreed upon by the state and the accused in the plea and sentencing agreement. ${ }^{46}$ It is because of this that his statement was not placed before the court. Even though the prosecutor later offered Mr Wickham a chance to adduce oral evidence in court before sentencing, the Magistrate refused to allow him that opportunity. His decision was influenced by information received that what purported to be a victim impact statement was actually a statement containing inconsistencies and further dealt with the merits of the case, not the impact of the crime on the victim. The Constitutional Court agreed that the decision whether or not to allow a victim to hand in an impact statement lies wholly within the discretion of the court. ${ }^{47}$

\section{Conclusion}

The contribution of the Wickham case to the South African criminal justice system is very valuable. It can be gleaned from the case that a victim of a crime lacks standing to challenge or review the actions of a Magistrate where he was denied a chance to submit a victim impact statement. Further, that victims are not party to criminal proceedings and as such they do not have an automatic right to present evidence.

It is also apparent from the case that victim impact statements should not deal with the merits of the case in a manner that differs from the agreed facts in terms of the section 105 plea, otherwise the victim may be disallowed from presenting his impact statement by the court. Further, that the DPP, as dominus litis, enjoys the exclusive right to take the Magistrate's exercise of discretion on review. Finally that the discretion to allow or disallow the victim impact statement lies solely with the presiding officer and, absent any improper exercise of this discretion by the presiding officer, a superior court will not set his decision aside. ${ }^{48}$

\footnotetext{
$46 \quad$ Wickham v Magistrate para 32.

$47 \quad$ Wickham v Magistrate para 31.

$48 \quad$ Wickham v Magistrate para 31.
} 


\section{Bibliography}

\section{Literature}

Baxter Administrative Law

Baxter A Administrative Law (Juta Cape Town 1984)

Chalmers, Duff and Leverick 2007 Crim LR

Chalmers J, Duff $P$ and Leverick $F$ "Victim Impact Statements: Can Work, Do Work (for Those who Bother to Make Them)" 2007 Crim LR 360-379

Currie and De Waal Bill of Rights Handbook

Currie I and De Waal J The Bill of Rights Handbook $6^{\text {th }}$ (Juta Cape Town 2013)

\section{Erez 1995 Crim LR}

Erez E "Who's Afraid of the Big Bad Victim? Victim Impact Statements as Victim Empowerment and Enhancement of Justice" 1999 Crim LR 545-556

Kelly 1987 Wayne L Rev

Kelly DP "Victims" 1987 Wayne L Rev69-86

Kurland and Water 1959 Duke Law School Journal

Kurland PB and Water DWM "Public Prosecution in England, 1854-79: An Essay in English Legislative History" 1959 Duke Law School Journal 493562

Lens et al 2015 Eur J Criminol

Lens KME et al"Delivering a Victim Impact Statement: Emotionally Effective or Counter-productive?" 2015 Eur J Criminol 17-34

Muller and Van der Merwe 2006 SAJHR

Muller $\mathrm{K}$ and Van der Merwe A "Notes and Comments Recognising the Victim in the Sentencing Phase: The Use of Victim Impact Statements in Court" 2006 SAJHR 647-663

SALC Sentencing

South African Law Commission Issue Paper 7, Project 82: Sentencing Restorative Justice (The Commission Pretoria 1997)

UN ODCCP Handbook on Justice for Victims

United Nations Office for Drug Control and Crime Prevention Handbook on Justice for Victims: On the Use and Application of the Declaration of Basic 
Principles of Justice for Victims of Crime and Abuse of Power (UN ODCCP New York 1999)

\section{Case law}

AParty v Minister of Home Affairs; Moloko v Minister of Home Affairs 2009 3 SA 649 (CC)

Booysen v Minister of Safety and Security 20186 SA 1 (CC)

Bruce v Fleecytex Johannesburg CC 19982 SA 1143 (CC)

Ferreira v Levin 19961 SA 984 (CC)

Minister of Police v NP Sosibo 2010 ZAKZPHC 102 (14 December 2010)

Nyathi v MEC for Health, Gauteng 20085 SA 94 (CC)

Uffindell t/a Aloe Hunting Safaris v Government of Namibia 2009 NAHC 51

Wickham v Magistrate, Stellenbosch 20171 SACR 209 (WCC)

\section{Legislation}

\section{Australia}

Victims' Charter Act 65 of 2006

\section{South Africa}

Constitution of the Republic of South Africa, 1996

Criminal Procedure Act 51 of 1977

Promotion of National Unity and Reconciliation Act 34 of 1995

\section{International instruments}

African Union Principles and Guidelines on the Right to Fair and Legal Assistance in Africa (2003)

Draft United Nations Convention on Justice and Support for Victims of Crime and Abuse of Power (2006)

United Nations Convention on the Elimination of All Forms of Discrimination Against Women (1979) 
United Nations Convention on the Rights of the Child (1989)

United Nations Declaration of Basic Principles of Justice for Victims of Crime and Abuse of Power (1985)

\section{List of Abbreviations}

Crim LR

CPA

DPP

Eur J Criminol

ODCCP

SAJHR

SALC

SCA

UN

Wayne L Rev
Criminal Law Review

Criminal Procedure Act 51 of 1977

Director of Public Prosecutions

European Journal of Criminology

Office for Drug Control and Crime

Prevention

South African Journal on Human Rights

South African Law Commission

Supreme Court of Appeal

United Nations

Wayne Law Review 